Agro-Science Journal of Tropical Agriculture, Food, Environment and Extension Volume 17 Number 2 (May 2018) pp. $58-64$

\title{
ISSN 1119-7455 \\ NUTRITION KNOWLEDGE AND FACTORS ASSOCIATED WITH ANTHROPOMETRIC AND HAEMATOLOGICAL INDICES AMONG FEMALE UNDERGRADUATE STUDENTS IN UNIVERSITY OF NIGERIA, NSUKKA
}

*Okafor, A.M., Nwazojie, I.Z. and Afiaenyi, I.C.

Department of Human Nutrition and Dietetics, Faculty of Agriculture, University of Nigeria, Nsukka

Corresponding author's email: adaobi.nwabunze@unn.edu.ng;

\begin{abstract}
Poor nutritional status among adolescents and young adults can have serious consequences on their health. This study assessed the nutrition knowledge, anthropometric, haematological indices and associated factors among female undergraduate students of University of Nigeria, Nsukka. Multistage sampling technique was used to select 500 respondents from four faculties of the University. Nutrition knowledge and food habit of the respondents were obtained using structured and validated questionnaire. Anthropometric measurements (weight and height), haemoglobin, haematocrit, malaria parasite and blood pressure were obtained. Statistical Package for Social Sciences version 18.0 was used for data analysis. Descriptive and inferential statistics were used for data analysis. Data were presented as frequencies, percentages, means and standard deviation. Relationships existing among variables at $p<0.05$ were determined using Pearson's correlation. Fair nutrition knowledge existed in $40.0 \%$ of the respondents. Anthropometric measurements revealed that $40.0 \%$ and $2.0 \%$ were overweight and severely obese, respectively. The prevalence of mild anaemia was $25.3 \%$ while $64 \%$ had for malaria parasite. Systolic and diastolic hypertension existed in $2.7 \%$ and $5.3 \%$, respectively. Significant $(p<0.05)$ relationship existed between haemoglobin and monthly allowance; malaria parasite; body mass index (BMI) and nutrition knowledge. Poor nutrition knowledge, obesity, malaria and anaemia existed among the respondents. Nutrition education is required and should be promoted amongst University students.
\end{abstract}

Keywords: Body mass index; food habits; blood pressure; malaria parasite; haemoglobin.

\section{INTRODUCTION}

Nutrition knowledge is an important factor in promoting healthier eating habits and consequently maintaining an appropriate body weight, thus preventing overweight and obesity (Kruger et al., 2002). Poor eating habits and lack of nutrition knowledge are important public health issues that have serious health implications (Andere and Kyallo, 2013). In University campuses, lack of a central feeding facility for students has forced students to take responsibility of their feeding (Achinihu, 2009). As a result, most students in Nigerian Universities lack funds or divert their feeding money for other needs and so skip meals. This predisposes them to malnutrition. According to Estima et al. (2009) and Levy et al. (2010) the most prevalent habits accustomed in this age group include changing main meals for snacks, skipping breakfast, reducing the intake of fruits and vegetables and increasing consumption of sodas and high calorie foods.

These habits can result in iron deficiency anaemia (IDA) and increase the risk of obesity (Zimmerman et al., 2008; Menzie et al., 2008). According to WHO (2011), anaemia is the most common intractable nutritional problem worldwide. Parasitic infections, inadequate iron intake and infectious diseases such as malaria are some predisposing factors that enhance the occurrence of anaemia. Adolescent girls are particularly prone to IDA because of increased demand of iron for haemoglobin, myoglobin and to make up for the loss of iron due to menstruation and poor dietary habits (Beard, 2000). Among young adults, IDA could be attributed to faulty feeding habits. Obesity, a leading cause of preventable death worldwide, is common among women than men (WHO, 2000). Arroyo et al. (2006) reported that University

Please cite as. Okafor, A.M., Nwazojie, I.Z. and Afiaenyi, I.C.(2018) Nutrition knowledge and factors associated with anthropometric and Haematological indices among female undergraduate students in University of Nigeria, Nsukka Agro Science 17 (2) 57-62 DOI: https://dx.doi.org/10.4314/as.v17i2.8 
students consume a lot of fast foods which is high in fats and has low intake of fruits and vegetables. High consumption of imported and processed foods which are highly refined, high in sugar, fats and salt coupled with less physical activity greatly contribute to rising chronic diseases even among young adults (Den Hartog, Stavereren \& Brouwer, 2006). Female university students are of interest because they have increased nutrient (especially micronutrients) needs. The transition in living environment and the freedom to make food choices among them may translate to good or bad nutritional status. This study assessed the nutrition knowledge, anthropometric, haematological indices and associated factors among female undergraduate students of the University of Nigeria Nsukka campus.

\section{MATERIALS AND METHODS}

This cross-sectional study was carried out in the University of Nigeria, Nsukka (UNN) campus. Four faculties with a female population of 2407 were randomly selected out of the nine faculties (female population of 6638 ) in UNN. Twenty per cent of the total female population were used for the study ( $n=481$ respondents). The sample population was further increased by $5 \%$ (24 respondents) to account for contingencies such as nonresponse or recording error (Yamane, 1967). The sample size was $24+481=505$ respondents. Five hundred correctly filled questionnaires (representing $20.8 \%$ of the total female population) were, however, collected at the end of the study. Multi-stage sampling technique was employed where four (population - 2407) out of nine (population 6638) faculties were randomly selected by balloting without replacement. Proportionate sampling was used to determine the number of respondents to be used in the selected faculties and their respective departments. Respondents were selected from their various departments and levels using random sampling by balloting without replacement. Fifteen per cent of the sample size was used for blood pressure, haematological parameters and malaria parasite assessment.

\section{Methods of data collection}

A preliminary visit was made to the faculties that were selected and the students in each level were informed about the study at the end of a lecture offered by all. Time and date for the study was chosen with the students to ensure that the researchers had at least one hour for data collection. Their consent to participate in the study was sought using an informed consent form which was signed by the selected respondents. A structured and validated questionnaire was used to obtain information on respondents' nutrition knowledge and food habits. Basic nutrition questions on food groups, metabolism of nutrients, sources, functions and deficiencies of nutrients were used to assess respondents' nutrition knowledge. The questions had one correct and three incorrect answers (i.e. multiple choices) from which the respondents chose their answers. Questions were marked and scored in percentages at the end of the study. Nutrition knowledge grading scale was adapted from Essien et al. (2014). Anthropometric measurements of weight and height were obtained from each respondent. Respondents were asked to stand in the centre of Hanson bathroom scale bare-footed with arms hanging at the sides and head, back and knees held comfortably erect. Weight was read and recorded to the nearest $0.1 \mathrm{~kg}$. Respondents stood bare-footed on the foot board of microtoise height metre with feet parallel to each other and back of feet, calves, buttocks, upper back and back of head touching the height metre. The head piece was lowered, crushing their hair and making contact with the top of their head. Height was read and recorded to the nearest $0.1 \mathrm{~cm}$. BMI of the respondents were calculated using the formula:

$$
\mathrm{BMI}=\frac{\text { Weight in } \mathrm{kg}}{\text { Height } \text { in }^{2}}=\mathrm{kg} / \mathrm{m} 2
$$

Respondents were classified as underweight, normal weight, overweight and obesity using World Health Organization (WHO) standard (WHO, 2000). Blood pressure of the respondents was measured using a digital sphygmomanometer and was classified using WHO (1999) standard for adults. Five millilitres of blood samples were collected using the vein puncture technique and were used for biochemical determinations. Haemoglobin and haematocrit were determined using the cyanmethaemoglobin and microhaematocrit methods, respectively. Malaria parasite determination was done using microscopy method (thick blood smear).

\section{Statistical analysis}

Data obtained were analysed using Statistical Package for Social Sciences (SPSS) version 18.0. Data was presented as means, standard deviation, frequencies and percentages. Pearson's correlation was used to determine relationships existing among variables at $\mathrm{p}<$ 0.05 . 


\section{RESULTS}

The socio-economic characteristics of the respondents is presented in Table 1. Majority $(97.0 \%)$ of the respondents were married and $63.0 \%$ were between $20-29$ years of age.

The Monthly allowance of $47.0 \%$ of the respondents was $\$ 5,500$ - $\$ 9,000$. Table 2 shows the nutrition knowledge of the respondents. Excellent, fair and poor nutrition knowledge existed among 16.0\%, 40.0\% and $3.0 \%$ of the respondents, respectively. Food habits of the respondents is shown in Table 3. Most of the respondents $(58.4 \%)$ ate twice a day and the source of food was mostly from food vendors (51.0\%). Sixty-three per cent of the respondents skipped meals. Of those who skipped meals, majority (92.1\%) skipped breakfast and the reason for skipping meals by most $(58.7 \%)$ of the respondents was that there was not enough time to eat. Fruits and vegetables were occasionally consumed by $34.4 \%$ and $51.0 \%$ of the respondents, respectively. The anthropometric index, haemoglobin, haematocrit, blood pressure and malaria parasite infestation status of the respondents are shown in Table 5 . Underweight (13.0\%), overweight (40.0\%), obesity class $1(7.6 \%)$, mild anaemia $(25.3 \%)$ and malaria parasite infestation $(64.0 \%)$ existed among the respondents (Table 5). Significant $(p<0.05)$ relationship existed among haemoglobin and monthly allowance; BMI and nutrition knowledge (Table 6). Body mass index was not significantly $(\mathrm{p}>0.05)$ associated with nutrition knowledge.

Table 1: Socio-economic characteristics of the respondents

\begin{tabular}{lll}
\hline Characteristics & Frequency & Percentage \\
\hline Marital status & & \\
Single & 485 & 97.0 \\
Married & 15 & 3.0 \\
Total & 500 & 100.0 \\
Age (years) & & \\
$18-20$ & 95 & 19.0 \\
$20-24$ & 315 & 63.0 \\
$25-29$ & 65 & 13.0 \\
$30-35$ & 25 & 5.0 \\
Total & 500 & 100.0 \\
Monthly & & \\
allowance (A) & & \\
$\leq 3,000-5,000$ & 120 & 24.0 \\
$5,500-9,000$ & 235 & 47.0 \\
$9,500-14,500$ & 80 & 16.0 \\
$\geq 15,000$ & 65 & 13.0 \\
Total & 500 & 100.0 \\
\hline
\end{tabular}

Table 2: Nutrition knowledge of the respondents

\begin{tabular}{lll}
\hline $\begin{array}{l}\text { Nutrition knowledge } \\
\text { scores }\end{array}$ & Frequency & Percentage \\
\hline Excellent $(70-100 \%)$ & 80 & 16.0 \\
Very good $(60-69 \%)$ & 120 & 24.0 \\
Good (50-59\%) & 85 & 17.0 \\
Fair $(30-49 \%)$ & 200 & 40.0 \\
Poor $(<30 \%)$ & 15 & 3.0 \\
Total & 500 & 100.0 \\
\hline
\end{tabular}

Source: Essien et al. (2014)
Table 3: Food habits of the respondents

\begin{tabular}{|c|c|c|}
\hline Variables & Frequency & Percentage \\
\hline \multicolumn{3}{|l|}{ Number of meals/day } \\
\hline One & & 4.6 \\
\hline Two & 292 & 58.4 \\
\hline Three & 165 & 33.0 \\
\hline Four & 20 & 4.0 \\
\hline Total & 500 & 100.0 \\
\hline \multicolumn{3}{|l|}{ Source of food } \\
\hline Food vendors & 255 & 51.0 \\
\hline Restaurants & 120 & 24.0 \\
\hline Food cooked by respondents & 100 & 20.0 \\
\hline Eats at home & 25 & 5.0 \\
\hline Total & 500 & 100.0 \\
\hline \multicolumn{3}{|l|}{ Skipped meals } \\
\hline Yes & 315 & 63.0 \\
\hline No & 185 & 37.0 \\
\hline Total & 500 & 100.0 \\
\hline \multicolumn{3}{|l|}{ Meals skipped } \\
\hline Breakfast & 290 & 92.1 \\
\hline Lunch & 4 & 1.2 \\
\hline Supper & 21 & 6.7 \\
\hline Total & 315 & 100.0 \\
\hline \multicolumn{3}{|l|}{ Reasons for skipping meals } \\
\hline To maintain body figure & 10 & 3.2 \\
\hline Not hungry & 70 & 22.2 \\
\hline To lose weight & 50 & 15.9 \\
\hline Not enough time to eat & 185 & 58.7 \\
\hline Total & 315 & 100.0 \\
\hline \multicolumn{3}{|l|}{ Vegetable consumption } \\
\hline Daily & 95 & 19.0 \\
\hline Occasionally & 255 & 51.0 \\
\hline Rarely & 150 & 30.0 \\
\hline Total & 500 & 100.0 \\
\hline \multicolumn{3}{|l|}{ Vegetable mostly consumed } \\
\hline Fluted pumpkin leaf & 80 & 16.0 \\
\hline Amaranthus & 112 & 22.4 \\
\hline Cucumber & 128 & 25.6 \\
\hline Carrot & 80 & 16.0 \\
\hline Tomatoes & 100 & 20.0 \\
\hline Total & 500 & 100.0 \\
\hline \multicolumn{3}{|l|}{ Fruit consumption } \\
\hline Daily & 98 & 19.6 \\
\hline Occasionally & 172 & 34.4 \\
\hline Rarely & 230 & 46.0 \\
\hline Total & 500 & 100.0 \\
\hline \multicolumn{3}{|l|}{ Fruit mostly consumed } \\
\hline Orange & 145 & 29.0 \\
\hline Apple & 19 & 3.8 \\
\hline Banana & 83 & 16.6 \\
\hline Pineapple & 6 & 1.2 \\
\hline Watermelon & 240 & 48.0 \\
\hline Pawpaw & 7 & 1.4 \\
\hline Total & 500 & 100.0 \\
\hline
\end{tabular}

Table 4: Mean anthropometric index, haemoglobin, haematocrit and blood pressure of the respondents

\begin{tabular}{ll}
\hline Variables & Mean \pm SD \\
\hline Anthropometric index & $1.56 \pm 0.74$ \\
Height (m) & $64.10 \pm 21.05$ \\
Weight $(\mathrm{kg})$ & $25.07 \pm 8.02$ \\
Body mass index $(\mathrm{kg} / \mathrm{m} 2)$ & $\mathbf{1 5 . 0 1} \pm \mathbf{2 . 8 2}$ \\
Haemoglobin $(\mathrm{g} / \mathbf{d l})$ & $\mathbf{3 8 . 1 2} \pm \mathbf{4 . 9 7}$ \\
Haematocrit $(\boldsymbol{\%})$ & \\
Blood pressure $(\mathbf{m m H g})$ & $80.34 \pm 13.30$ \\
Systolic pressure & $79.12 \pm 14.43$ \\
Diastolic pressure & \\
\hline
\end{tabular}


Nutrition Knowledge and Anthropometric/Haematological Indices Among Female Undergraduates

\section{DISCUSSION}

Inadequate nutrition knowledge observed among the students was a thing of concern because lack of nutrition knowledge happens to be an important public health issue that has serious health implications (Andere \& Kyallo, 2013). The occasional consumption of vegetables and rare consumption of fruits by the respondents is worrisome. Low intake of fruits and vegetables was observed by Adu et al. (2009) among students of Lagos state University, Ojo campus. Lack of adequate knowledge of the cumulative effects of eating habits may have caused the poor eating habits seen among the students. Breakfast, the most important meal for the day, was skipped by almost all the respondents with not having enough time to eat being a major reason. This is similar to earlier report among female undergraduate students in Osun state where 59\% skipped breakfast (Olumakaiye et al., 2010). Skipping breakfast may lead to hunger in the morning and result in increased snacking or food consumption during the day leading to excessive consumption of food/snacks which may predispose them to overweight and obesity. More than half of the respondents were either overweight or obese. Olumakaiye et al. (2010) had a lower prevalence for overweight and obesity among female undergraduate students of Obafemi Awolowo University, Ile-Ife, Nigeria contrary to the findings of this study. High normal blood pressure and stage 1 hypertension existed among the respondents showing that the students could be at risk of developing hypertension in later life which may predispose them to other non-communicable diseases (NCDs). This is similar to the findings of Bimenya et al. (2005) who reported that undergraduate students in Uganda have systolic and diastolic blood pressure values of clinical pre-hypertension and hypertension. Although it is commonly believed that essential hypertension usually begins between 35 and 45 years and worsens with age, our findings show imminent danger of hypertension in a young adult population of 18 - 35 years. Mild anaemia seen in a quarter of the respondents is worrisome. The prevalence of iron deficiency anaemia in this population, however, may be higher than the prevalence reported because most individuals are likely to be iron deficient long before there is a detectable drop in blood haemoglobin levels (Kennedy, Nantel and Shetty, 2003). Malaria parasite infestation may have contributed to this. Young female adults are at increased risk of IDA due to consumption of energy-dense diets (Hendricks, Herbold and Fung, 2004), increased iron demand, menstrual losses, insufficient dietary iron intake (especially of animal origin), faulty dietary habits and limited financial resources and making the transition from home to independent living. Infections and parasitic diseases, in particular malaria, helminth infestations and urinary tract infections are also important factors contributing to the high prevalence of anaemia in sub-Saharan Africa (Asobayire et al., 2001).

Among undergraduate students in Nnamdi Azikiwe University Awka, Ezugbo-Nwobi et al .2011) reported a 64\% prevalence of malaria parasite infestation similar to the findings of this study. Findings of this study were higher than the $61.1 \%$ and $17 \%$ reported among undergraduates in Abuja (Mature, Azare and Ugbong, 2001) and Ibadan (Anumudu et al., 2006), respectively. The natural vegetation seen around students' hostels which probably serve as breeding ground for mosquitoes may have contributed to this high prevalence. Monthly allowance was significantly $(\mathrm{p}<0.05)$ associated with BMI similar to earlier findings (Ibeanu, Onyechi \& Onuoha, 2012). This has serious implication on the health of the respondents because those with high monthly allowance were more likely to eat out and their food selection may be based on food palatability, availability and convenience predisposing them to overweight and obesity. Those who had more monthly allowance were probably able to afford animal sources of protein such as meat which are known to be good sources of haem iron. This might be the reason for the positive correlation of haematocrit, haemoglobin and monthly allowance. BMI was positively correlated with haemoglobin and haematocrit. According to Paknahad et al. (2008) iron stores of obese women are higher than non-obese women. This is contrary to earlier report (Amato et al., 2010) that anaemia is found in obese individuals and could be attributed to the role of hepcidin (mediator of inflammation which is up-regulated in obesity) mediated inhibition of dietary iron absorption which in turn leads to anaemia. Nutrition knowledge was a factor that was positively correlated with haemoglobin and indicating that those with sufficient nutrition knowledge were probably able to combine foods from different food groups for optimum nutrition and good health. 
Okafor, A.M., Nwazojie, I.Z. and Afiaenyi, I.C.

Table 5: Anthropometric and biochemical indices status of the respondents

\begin{tabular}{|c|c|c|}
\hline Variables & Frequency & Percentage \\
\hline \multicolumn{3}{|l|}{ Body mass index (kg/m2) } \\
\hline Underweight $(>18.5)$ & 65 & 13.0 \\
\hline Normal (18.5-24.9) & 165 & 33.0 \\
\hline Overweight (25.0-29.9) & 200 & 40.0 \\
\hline Obese class $1(30.0-34.9)$ & 38 & 7.6 \\
\hline Obese class $11(35.0-39.9)$ & 22 & 4.4 \\
\hline Obese class $111(\geq 40.0)$ & 10 & 2.0 \\
\hline Total & 500 & 100.0 \\
\hline \multicolumn{3}{|l|}{ Haemoglobin (g/dl) } \\
\hline Severe anaemia $(<7)$ & 0 & 0.0 \\
\hline Moderate anaemia (7-9.9) & 0 & 0.0 \\
\hline Mild anaemia (10.0-11.9) & 19 & 25.3 \\
\hline Normal $(\geq 12.0)$ & 56 & 74.7 \\
\hline Total & 75 & 100.0 \\
\hline \multicolumn{3}{|l|}{ Haematocrit (\%) } \\
\hline Normal (35-50) & 56 & 74.7 \\
\hline Mild (27-33) & 19 & 25.3 \\
\hline Total & 75 & 100.0 \\
\hline \multicolumn{3}{|l|}{ Systolic blood pressure (mmHg) } \\
\hline Normal (120-129) & 59 & 78.6 \\
\hline High normal (130-139) & 14 & 18.7 \\
\hline Stage 1 or mild hypertension (140-159) & 2 & 2.7 \\
\hline Total & 75 & 100.0 \\
\hline \multicolumn{3}{|l|}{ Diastolic blood pressure $(\mathrm{mmHg})$} \\
\hline Normal $(80-84)$ & 65 & 86.7 \\
\hline High normal (85-89) & 6 & 8.0 \\
\hline Stage 1 hypertension (90-99) & 4 & 5.3 \\
\hline Total & 75 & 100.0 \\
\hline \multicolumn{3}{|l|}{ Malaria parasite status } \\
\hline Absent & 27 & 36.0 \\
\hline Present & 48 & 64.0 \\
\hline Total & 75 & 100.0 \\
\hline
\end{tabular}

Table 6: Relationship between some factors that affect anthropometric index and haematological indices

\begin{tabular}{llllll}
\hline & $\mathrm{r}, \quad \mathrm{p}$ values & & $\mathrm{r}, \quad \mathrm{p}$ values \\
\hline Haemoglobin and monthly allowance & $0.578^{* *}$, & 0.000 & Haematocrit and monthly allowance & $0.462^{* *}$, & 0.000 \\
Haemoglobin and malaria parasite & $-0.674^{* *}$, & 0.008 & Haematocrit and malaria parasite & $-0.718^{* *}$, & 0.002 \\
Haemoglobin and body mass index & $0.487^{* *}$, & 0.000 & Haematocrit and body mass index & $0.822^{* *}$, & 0.001 \\
Haemoglobin and nutrition knowledge & $0.827^{* *}$, & 0.005 & Haematocrit and nutrition knowledge & $0.271^{*}$, & 0.019 \\
Body mass index and monthly allowance & $0.577^{* *}$, & 0.010 & $\begin{array}{l}\text { Body mass index and nutrition } \\
\text { knowledge }\end{array}$ & 0.099, & 0.400 \\
\hline
\end{tabular}

Level of significance: $* * \mathrm{p}<0.01$

$* \mathrm{p}<0.05$

The significant $(\mathrm{p}<0.05)$ but negative relationship which existed between malaria parasite infestation and haemoglobin is not surprising and may be due to increased extravascular haemolysis of red blood cells with a concomitant failure of the bone marrow to increase red cell production to compensate for these losses (Lamikanra et al., 2007).

\section{CONCLUSION}

Fair nutrition knowledge, anaemia, obesity and hypertension existed among this population. The findings of this study reveal a high prevalence of malaria parasite. Vegetables and fruits were occasionally and rarely consumed by the respondents. Significant $(p<0.05)$ relationships existed between nutrition knowledge, monthly allowance and BMI; and haemoglobin. Negative but significant ( $\mathrm{p}<$ 0.05) relationship existed between haemoglobin and haematocrit; and malaria parasite. Nutrition education is imminent for University students to gain appropriate knowledge about nutrition and periodic screening of blood pressure is important.

\section{REFERENCES}

Achinihu G. (2009). Nutritional status of university students in south-eastern states of Nigeria. Journal of Research in National Development 7 (2). 
Adu O.B. Falade A.M. Nwalutu E.J. Elemo B.O. and Magbagbeola O. A. (2009). Nutritional status of undergraduates in a Nigerian university in south-west Nigeria. International Journal of Medicine and Medical Sciences1 (8), 318-324.

Amato A. Santoro N. Calabro P. Grandone A. Swinkels D.W. and Perrone L. (2010). Effect of body mass index reduction on serum hepcidin levels and iron status in obese children. International Journal of Obesity 34, 1772-1774.

Andere A.A. and Kyallo F.M. (2013). Nutritional status, nutrition knowledge and attitudes of students in Jomo Kenyatta University of Agriculture and Technology. Digital repository of Jomo Kenyatta University of Agriculture and Technology 167-172.

Anumudu C.I. Adepoju A. Adediran M. Adeoye O. Kassim A. Oyewole I. and Nwuba R. I. (2006). Malaria prevalence and treatment seeking behavior of young Nigerian adults. Annals of African Medicine 5 (2), 82-88.

Arroyo I.M. Rocandio P.A.M. Ansotegui A.L. Pasual A.E. Salces B.I. and Rebato O. E. (2006). Diet quality, overweight and obesity in universities' students. Nutricion Hospitalaria 21 (6), 673-679.

Asobayire F. S. Adou P. Davidsson L. Cook J.D. and Hurrell R.F. (2001). Prevalence of iron deficiency with and without concurrent anemia in population groups with high prevalences of malaria and other infections: a study in Côte d'Ivoire. American Journal of Clinical Nutrition 74 (6), 776-782.

Beard J.L. (2000). Iron requirements of adolescent females. American Journal of Clinical Nutrition 130440 S-442S.

Bimenya G.S. Byarugaba W. Kalungi S. Mayito J. Mugabe K. Makabayi R. Ayebare E. Wanzira H. and Muhame M. (2005). Blood pressure profiles among Makerere University undergraduate students. African Health Sciences 5 (2) 99-106.

Den Hartog A. Stavereren W. and Brouwer I. (2006). Food habits and consumption in developing countries. Manual for field studies. Netherlands: Wageningen academic publishers.

Essien E. Emebu P.K. Iseh K.R. and Haruna M.J. (2014). Assessment of nutritional status and knowledge of students from selected secondary schools in Sokoto metropolis, Sokoto state, Nigeria. African Journal of Food, Agriculture, Nutrition and Development 14 (6), $9454-9468$.

Estima C.P. Salles-Costa R. Sichieri R. Pereira R.A. and Veiga G.V. (2009). Meal consumption patterns and anthropometric measures in adolescents from a low socioeconomic neighbourhood in the metropolitan area of Rio de Janeiro, Brazil. Appetite 52 735-739.
Ezugbo-Nwobi I.K. Obiukwu M.O. Umeanato P.U. and Egbuche C.M. (2011). Prevalence of malaria parasites among Nnamdi Azikiwe university students and anti-malaria drug use. African Research Review 5 (4), 135-144.

Hendricks K.M. Herbold N. and Fung T. (2004). Diet and other lifestyle behaviours in young college women. Nutrition Research 24, 981991.

Ibeanu V.N. Onyechi U.A. and Onuoha N.O. (2012). Prevalence of underweight, overweight and obesity among underweight students of the University of Nigeria Nsukka campus. Journal of Human Epidemiological Research 17, 230241.

Kennedy G. Nantel G. and Shetty P. (2003). The scourge of hidden hunger: global dimensions of micronutrient deficiencies. Food, Nutrition and Agriculture 32 8-16.

Kruger H.S. Venter C.S. Vorster H.H. and Margetts B.M. (2002). Physical activity is a major determinant of obesity in black women in the north west province, South Africa: the THUSA study. Nutrition 18 (5), 422-427.

Lamikanra A.A. Brown D. Potocnik A. CasalsPascual C. Langhorne J. and Roberts D.J. (2007). Malarial anaemia: of mice and men. Blood 110, 18-28.

Levy R.B. Castro I.R.R.. Cardoso L.O. Tavares L.F. Sardinha L.M.V. Gomes F.S. and da Costa A.W.N. (2010). Food consumption and eating behavior among Brazilian adolescents: National Adolescent School based Health Survey (PeNSE), 2009. Ciecia and Saude Coletiva 15 (2), 3085-3097.

Mature B.M. Azare B.A. and Ugbong L. (2001). The prevalence of malaria parasites amongst undergraduate students of University of Abuja. The Nigerian Journal of Parasitology 22 (182), 49-82.

Menzie C.M. Yanoff L.B. Denkinger B. McHugh T. Sebring N.G. and Calis K.A. (2008). Obesity-related hypoferremia is not explained by differences in reported intake of heme and nonheme iron or intake of dietary factors that can affect iron absorption. Journal of American Dietetics Association 108 (1), 145-148.

Olumakaiye, M. F., Ogbimi, G. E., Ogunba, B. O. and Soyebo, K. O. (2010). Snacking as a contributor to overweight among Nigerian undergraduate students. Nigerian Journal of Nutritional Sciences 31(2): 76-80.

Paknahad Z. Mahboob S. Omidvar N. Ebrahimi M. Ostadrahimi A. and Afiatmilan S. (2008). Body mass index and its relationship with haematological indices in Iranian women. Pakistan Journal of Nutrition 7 (2), 377-380.

World Health Organization (1999). International society of hypertension guidelines for management of hypertension. Journal of Hypertension 17, 151-183.

World Health Organization. (2000). Obesity: preventing and managing the global epidemic. Report of a WHO Consultation on obesity. WHO Technical Report Series 894, 1-253. 
World Health Organization. (2011). Prevention of iron deficiency anaemia in adolescents: role of weekly iron and folic acid supplementation. Geneva: World Health Organization.

Yamane T. (1967). Statistics: An introductory analysis. 2nded. New York: Harper and Row.
Zimmerman M.B. Zeder C. Muthayya S. Winichagoon P. Chaouki N. and Aeberli I.(2008). Adiposity in women and children from transition countries predicts decreased iron absorption, iron deficiency and a reduced response to iron fortification. International Journal of Obesity London 32 (7), 1098-1104. 